\title{
Circulating immune complexes in patients with lung cancer
}

\author{
JULIA LOWE, AMADA SEGAL-EIRAS, P B ILES AND R W BALDWIN \\ From Cancer Research Campaign Laboratories, University of Nottingham, Nottingham
}

ABSTRACT Sera from 41 patients with lung cancer and 41 age and sex-matched hospital in $-\stackrel{\circ}{\rightarrow}$ patients with non-malignant disease were tested for the presence of immune complexes using the ${ }^{125}$ Iodine Clq binding test. All patients were untreated or had recurrences after surgery. Ano increased Clq binding activity was found in $34 \%$ of patients with lung cancer and $24 \%$ of patients with non-malignant disease. There was no significant association between increased serum Clq binding activity and histological tumour type or survival but there was an association with the extent of malignant disease. No patient with limited (stage 1) disease had raised Clq binding activity but in $42 \%$ of patients with extensive disease it was increased. Increased $-\overrightarrow{0}$ Clq binding activity did not correlate with either an increased total white cell count or ESR. $\stackrel{\infty}{-}$ Measurement of Clq binding activity may be of value in serial monitoring of disease progressi and response to treatment.

Considerable interest has been shown in the measurement of circulating immune complexes in patients with malignant disease as a possible approach to immunodiagnosis or prognosis. ${ }^{1-4}$ This was originally stimulated by the description of factors in the serum of tumour-bearing patients and animals which interfere with cell-mediated immunity. ${ }^{5}$ It has also been suggested that circulating or cell-bound immune complexes may be responsible for the relatively high frequency of serum antiglobulin responses in cancer patients, ${ }^{67}$ and signs and symptoms of so-called "immune complex disease" may be seen in patients with cancer. ${ }^{9}$ More recently it has been suggested that immune complexes cause synthesis and release of prostaglandins and release of lysosomal acid hydrolysases from macrophages. ${ }^{10}$

Various methods have been used for the detection and quantitation of immune complex (CIC) levels in serum including the Raji cell binding assay and tests measuring binding of the Clq component of complement. ${ }^{41}$ Using these tests raised CIC levels have been reported in patients with lymphomas as well as many types of solid tumour. ${ }^{34}$ In many studies, however, patients with well established disease were studied and reports

Address for reprint requests: Dr J Lowe, Senior Medical Registrar, University Hospital, Nottingham NG7 2RD. from different groups have been contradictory. We describe here the measurement of serum CIC by radioprecipitation of ${ }^{125} \mathrm{I}-\mathrm{Clq}$ in patients with lung cancer compared with a group of hospital in patients with non-malignant disease and normap. young healthy control subjects.

\section{Methods}

Blood samples were taken from 41 patients with histologically confirmed lung cancer and 41 age and sex-matched hospital inpatients with benign conditions (excluding patients with diseases known to be associated with high levels of immune com plexes), and allowed to clot at room temperature for one hour. Serum was separated, the lipid layef removed after centrifugation at $1500 \mathrm{~g}$ for $15 \mathrm{~min}$ at $4^{\circ} \mathrm{C}$ and then $30000 \mathrm{~g}$ for $30 \mathrm{~min}$ at $4^{\circ} \mathrm{C}$ an\& the samples stored at $-70^{\circ} \mathrm{C}$. Immune complexes were assayed in duplicate by a modified ${ }^{125} \mathrm{I}$-Clof binding test in which ${ }^{125} \mathrm{I}-\mathrm{Clq}$ is added to heparin ised serum and complexes precipitated with polyo ethylene glycol.412 Histology was provided by the routine hospital pathology service and patients classified retrospectively as limited discase (stage $1 \Phi$ or extensive disease (stages 2 and 3 or deeme inoperable because of tumour spread). Survival aq one year after diagnosis and sampling was detere 
mined from the case notes and by contacting the patient's general practitioner where necessary. Three patients in the control group were excluded as further investigation revealed that they had been treated recently for other tumours or were suspected of having other tumours on clinical grounds. Clq binding activity was considered to be abnormal if it was more than two standard deviations greater than the mean level of $\mathrm{Clq}$ binding activity in 20 healthy laboratory personnel -that is, greater than $11 \%$ Clq binding activity.

Table 1 Results of Clq binding activity tests

\begin{tabular}{|c|c|c|}
\hline & Lung cancer & $\begin{array}{l}\text { Benign } \\
\text { conditions }\end{array}$ \\
\hline $\begin{array}{l}\text { Number tested } \\
\text { Mean age (yr) } \\
\text { Mean Clq binding } \\
\text { activity } \pm \text { SD } \\
\text { Number of tests positive } \\
(>11 \cdot 1 \%) \\
\text { Number of tests negative } \\
(<11 \cdot 1 \%)\end{array}$ & $\begin{array}{l}41 \\
61 \pm 9 \\
11 \cdot 5 \pm 11 \cdot 8 \% \\
14 \\
28\end{array}$ & $\begin{array}{l}38 \\
63 \pm 14 \\
7 \cdot 3 \pm 5 \cdot 0 \% \\
8 \\
30\end{array}$ \\
\hline
\end{tabular}

\section{Results}

Thirty-four per cent of lung cancer patients and $24 \%$ of hospital control subjects had abnormally high levels of $\mathrm{Clq}$ binding activity (table 1). Although the highest levels were seen in the lung cancer patients and the mean value was greater than that of the controls, this did not reach statistical significance (Mann-Whitney U test). As the values of Clq binding activity in the two control groups were not normally distributed, the results from the lung cancer patients and the healthy and hospital control subjects combined were compared after log transformation.

There was no association between an increased Clq binding activity and histology or survival (table 2). However, there was a significant association between disease extent and an abnormally high test (table 3). All seven patients with limited disease had negative tests while $42 \%$ of patients
Table 3 Association between extent of disease and test results

\begin{tabular}{llll}
\hline Stage & $C l q B A>11 \cdot 1 \%$ & $C l q B A<11 \cdot 1 \%$ & \\
\hline Limited & 0 & 7 & 7 \\
Extensive & 14 & 19 & 33 \\
& 14 & 26 & $40^{*}$
\end{tabular}

*One patient extent not known. $\mathrm{p}=0.03$ Student's $t$ test.

Limited =stage 1 , extensive $=$ stages 2 and 3 .

with extensive disease had positive tests $(p=0 \cdot 03)$. The mean Clq binding activity in patients with extensive disease $(12.7 \pm 13.0 \%)$ was significantly higher than that in patients with limited disease $(6.0 \pm 1.0 \%, \mathrm{p}<0.005$, Student's $t$ test $)$. Eleven of the 14 patients with elevated Clq binding activity were dead within six months of the test. The remaining three patients all had stage 2 squamous cell carcinoma treated with radical surgery.

There was no correlation between increased $\mathrm{Clq}$ binding activity and either a raised ESR or raised white cell count, or between survival and these factors.

\section{Discussion}

Although Clq binding may be increased by factors other than circulating immune complexes, such as infection, or macromolecules such as DNA and heparin, these were eliminated as far as possible both in patients and controls. Nevertheless there is almost complete overlap between the carcinoma and control groups which cannot be explained entirely by minor infection in the latter as these include one healthy staff member who has a persistently raised $\mathrm{Clq}$ binding activity, a diabetic with hypoglycaemia and no evidence of infection, and a patient with a recent stroke and no evidence of infection. Although other patients in the control group with raised $\mathrm{Clq}$ binding activity had exacerbations of chronic obstructive airways disease, by no means all patients with clinical evi-

Table 2 Relation between Clq binding activity and histology or survival

\begin{tabular}{|c|c|c|c|c|c|c|c|}
\hline \multicolumn{4}{|c|}{ Survival } & \multicolumn{4}{|l|}{ Histology } \\
\hline Time & ClqBA $>11 \cdot 1 \%$ & $C l q B A<11 \cdot 1 \%$ & Total & Type & $C l q B A>11 \cdot 1 \%$ & $C l q B A<11 \cdot 1 \%$ & Total \\
\hline \multirow[t]{3}{*}{$\begin{array}{l}>4 / 12 \\
<4 / 12\end{array}$} & $\begin{array}{l}7 \\
7\end{array}$ & $\begin{array}{l}17 \\
8\end{array}$ & $\begin{array}{l}24 \\
15\end{array}$ & $\begin{array}{l}\text { Squamous } \\
\text { Adeno }\end{array}$ & $\begin{array}{l}8 \\
0\end{array}$ & $\begin{array}{r}11 \\
2\end{array}$ & $\begin{array}{r}19 \\
2\end{array}$ \\
\hline & 14 & 25 & $39 * \mathrm{NS}$ & $\begin{array}{l}\text { Oat cell } \\
\text { Anaplastic } \\
\text { Other/not known }\end{array}$ & $\begin{array}{l}4 \\
1 \\
1\end{array}$ & $\begin{array}{l}7 \\
5 \\
2 \\
\end{array}$ & $\begin{array}{r}11 \\
6 \\
3 \\
\end{array}$ \\
\hline & & & & & 14 & 27 & 41 \\
\hline
\end{tabular}

*Two patients' survival not known.

Mean ClqBA in those who survived $<4 / 12=12 \cdot 57 \pm 9 \cdot 4$

Mean ClqBA in those who survived $>4 / 12=8 \cdot 89 \pm 7 \cdot 5$

$P<0.02$, Students' $t$ test. 
dence of chest infection had a raised $\mathrm{Clq}$ binding activity. It seems unlikely, therefore, that measurement of Clq binding activity will be either a useful screening or diagnostic test for lung cancer. However, patients with extensive disease (stage 2 or 3) and a raised Clq binding activity seem to have a particularly poor prognosis, and if this is confirmed $\mathrm{Clq}$ binding activity may prove to be a useful marker for the experimental prediction of outcome and serial monitoring of disease.

The overall prevalence of elevated serum Clq binding levels found in lung cancer patients (34\%) is much lower than that reported previously in other studies. For instance, Rossen et al ${ }^{11}$ detected positive reactions in 18 of $20(90 \%)$ patients with clinically apparent lung cancer and although Heier $e t a l^{3}$ reported a lower prevalence of elevated values, 16 of $24(67 \%)$ patients had positive results. This rose to 18 of $24(75 \%)$ in patients with disseminated disease. In both these studies, the control populations were healthy blood donors, and the upper normal limit was taken as 4.0 and $4.7 \% \mathrm{Clq}$ binding respectively. This is considerably lower than the base line levels established in this study using the modified Clq assay with appropriately age-matched controls (mean $7 \cdot 3 \pm 5 \cdot 0 \%$ ) and also with the normal value established in the laboratory with healthy donors $(6 \cdot 1 \pm 2 \cdot 5 \%)$. In this respect, it is pertinent that there was no significant difference in the serum Clq binding levels of the young healthy control population and the age-matched controls with the lung cancer patients, this group comprising inpatients with benign conditions. From these considerations it is clear that the lower prevalence of elevated Clq binding sera in the lung cancer patients reported here is to some extent the result of the control baseline. This is further emphasised by the observed mean Clq binding value in our lung cancer patients $(11.5 \pm 11.8 \%)$ when compared to that reported by Rosen et al ${ }^{11}(13.66 \pm 9 \%)$ and Heir et $a l^{3}(12 \cdot 0 \pm 18 \cdot 1 \%)$. In our other studies elevated serum Clq binding levels compared to the normal base line value of $6 \cdot 1 \pm 2.5 \%$ have been observed in carcinoma of breast ${ }^{12}$ and osteogenic sarcoma. ${ }^{13}$ For example, 42 of $62(68 \%)$ sera from patients with osteogenic sarcoma showed elevated $\mathrm{Clq}$ binding values (mean $30 \cdot 3 \pm 11 \cdot 4 \%$ ). Accordingly, it is concluded that there was no overall increase in serum Clq binding levels in patients with lung cancer. The numbers of patients with different histological types were not sufficient for analysis. However, considering disease stage it is evident that only patients with extensive disease showed elevated serum Clq values.
The absence of a correlation of serum Clq levels with total white blood cell count or erythrocyte sedimentation rate suggests that a raised $\mathrm{Clq}$ binding activity in patients with lung cancer is caused by factors other than intercurrent infection. The association with extent of disease confirms that reported previously ${ }^{311}$ and explains the correlation with survival, patients with extensive disease having a poorer overall prognosis.

From our data it seems unlikely that measure ment of $\mathrm{Clq}$ binding activity will be of value in initial diagnosis and staging of lung cancer, but it may prove useful in association with other tests of tumour burden for prognosis and assessing response to treatment.

\section{References}

1 Theofilopoulos AN, Wilson CB, Dixon FJ. The Raji cell radioimmune assay for detecting immune complexes in human sera. J Clin Invest 1976; 57: 169-82.

2 Samayoa EA, McDuffie FC, Nelson AM, Go VL Luthra HS, Brumfield HW. Immunoglobulin complexes in sera of patients with malignancy. Int $J$ Cancer 1977; 19:12-17.

3 Heier HE, Carpentier N, Lange G, Lambert RH, Godal T. Circulating immune complexes in patients with malignant lymphomas and solid tumors. Int J Cancer 1977; 20:887-94.

4 Baldwin RW, Byers VS, Robins RA. Circulating immune complexes in cancer: characterization and potential as tumour markers. Behring Inst Mitt 1979; 64:63-77.

5 Baldwin RW, Price MR. Tumor antigens and tumor-host relationships. Ann Rev Med 1976; 27 : 151-63.

6 Hartmann D, Lewis MG. Presence and possible role of anti-IgG antibodies in human malignancy. Lancet 1974; 1:1318-20.

7 Twomey JJ, Rossen RD, Lewis VM, Laughter $\mathrm{AH}$, Douglas CC. Rheumatoid factor and tumor host interaction. Proc Natl Acad Sci USA 1976; 73:2106-8.

8 Levine GB, Mills PE Jr, Epstein WV. Circulating IgG globulin anti-IgG globulin complex in a patient with carcinoma of the lung and severe neuromyopathy. J Lab Clin Med 1967; 69:749-57.

9 Couser WG, Wagonfield JB, Spargo BH, Lewis EJ. Glomerular deposition of tumor antigen in membranous neptropathy associated with colonic carcinoma. Am J Med 1974; 57:962-70.

10 Bonney RJ, Wightman PD, Davies P, Humes JL Immune complexes cause the synthesis and release of lysosomal acid hydrolysis from macrophages. Eur $J$ Rheumatology and Inflammation 1979; 2:230.

11 Rossen RD, Reisberg MA, Hersh EM, Gutterman 
JU. The Clq binding test for soluble immune complexes: clinical correlations obtained in patients with cancer. J Natl Cancer Inst 1977; 58:1205-15.

12 Hoffken K, Meredith ID, Robins RA, Baldwin RW, Davies CJ, Blamey RW. Circulating immune complexes in patients with breast cancer. $\mathrm{Br} \mathrm{Med}$ J 1977; 2:218-20.

13 Segal-Eiras A, Robins RA, Byers VS, Baldwin RW. Circulating immune complexes in patients with bone tumours. Int J Cancer 1980; 25:735-9. 